\title{
PROGRESSIVE MUSCLE RELAXATION DAN SLOW DEEP BREATHING PADA PENDERITA HIPERTENSI
}

\author{
Niken Setyaningrum ${ }^{1, *}$, Iman Permana ${ }^{2}$, Falasifah Ani Yuniarti² \\ ${ }^{1}$ Program Studi Ilmu Keperawatan, Stikes Surya Global, Yogyakarta, Indonesia \\ ${ }^{2}$ Magister Keperawatan, Universitas Muhammadiyah Yogyakarta, Indonesia \\ *)E-mail : nik3nimo3t@gmail.com
}

Dikirim: Maret 2017, diterbitkan: April 2017

\begin{abstract}
ABSTRAK
Tujuan penelitian: untuk mengetahui efektivitas teknik progressive muscle relaxation dan slow deep breathing terhadap peningkatan kualitas tidur dan penurunan tingkat stres. Metode: penelitian ini menggunakan quasi experimental design with comparison group. Pengambilan sampel penelitian menggunakan purposive sampling. Penelitian dilakukan di wilayah kerja Puskesmas Gamping 2 Yogyakarta. Besar sampel dalam penelitian ini sebanyak 60 responden dengan pembagian sampel masing-masing 20 responden pada kelompok intervensi, kelompok kontrol 1, dan kelompok kontrol 2. Pengambilan data dilakukan pada bulan April sampai Juni 2015. Instrumen penelitian ini menggunakan PSQI (Pittburgh Sleep Quality Index) untuk mengukur kualitas tidur dengan nilai validitas 0,89 dan reliabilitas sebesar 0,73, sedangkan PSS (Perceived Stress Scale) untuk mengukur tingkat stres dengan nilai validitas 0,85 dan reliabilitas sebesar 0,75. Analisis data dalam penelitian ini menggunakan Anova dilanjutkan uji post-hoc Bonferroni. Hasil: Terdapat perbedaan yang signifikan antara kelompok intervensi, kelompok kontrol 1, dan kelompok kontrol 2 terhadap peningkatan kualitas tidur $(\mathrm{p}=0,025)$. Terdapat perbedaan yang signifikan antara kelompok intervensi, kelompok control 1 dan kelompok kontrol 2 terhadap penurunan tingkat stres $(\mathrm{p}=0,009)$. Diskusi: Hipertensi berkaitan dengan kualitas tidur dan tingkat stres karena berhubungan dengan respons saraf simpatis. Jika tidak diidentifikasi dengan baik, hal tersebut dapat memperburuk kondisi penderita hipertensi. Hipertensi dapat dikontrol dengan terapi nonfarmakologi menggunakan teknik relaksasi progressive muscle relaxation dan slow deep breathing. Kesimpulan: teknik progressive muscle relaxation efektif untuk meningkatkan kualitas tidur dan slow deep breathing efektif untuk menurunkan tingkat stres.
\end{abstract}

Kata Kunci: hipertensi, kualitas tidur, tingkat stres, progressive muscle relaxation, slow deep breathing

\section{PROGRESSIVE MUSCLE RELAXATION AND SLOW DEEP BREATHING IN HYPERTENSION PATIENTS}

ABSTRACT

Objective: to identify the effectiveness of progressive muscle relaxation and slow deep breathing on improving sleep quality and decreasing stress levels. Methods: This study employed quasi experimental design with comparison group. Samples were taken using purposive sampling. The study was conducted in the working area of Puskesmas (Public Health Center) Gamping 2 Yogyakarta. The sample size was 60 respondents with 20 respondents in each of the intervention group, control group 1, and control group 2. Data were collected from April to June 2015. The research used PSQI (Pittsburgh Sleep Quality Index) to measure the quality of sleep with a validity value of 0.89 and a reliability value of 0.73 and PSS (Perceived Stress Scale) to measure stress levels with a validity value of 0.85 and a reliability value of 0.75. Data were analyzed using Anova and followed by using Bonferroni post-hoc test. Results: There were significant differences between intervention group, control group 1, and control group 2 in the sleep quality improvement $(p=0.025)$. There were significant differences between intervention group, control group 1 and control group 2 in the decreased stress levels ( $p=0,009)$. Discussion: Hypertension is related to sleep quality and stress levels because it is associated with sympathetic nerve response. Unless they are well identified, they may worsen the condition of patients with hypertension. Hypertension can be controlled 
with non-pharmacological therapy using progressive muscle relaxation and slow deep breathing relaxation. Conclusion: Progressive muscle relaxation is effective to improve sleep quality and slow deep breathing is effective to reduce stress level. Keywords: hypertension, sleep quality, stress level, progressive muscle relaxation, slow deep breathing

\section{LATAR BELAKANG}

Salah satu wujud usaha untuk mencapai tujuan pembangunan kesehatan setiap ialah orang hendaknya berperilaku hidup sehat. Saat ini telah terjadi perubahan hidup sehat atau gaya hidup seseorang, yaitu konsumsi makanan siap saji (fast food) yang mengandung kadar lemak jenuh yang tinggi, kebiasaan merokok, minum minuman beralkohol, kerja berlebihan, kurang berolahraga, dan stres (Adriani \& Wirjatmadi, 2012). Hal tersebut berdampak terhadap pergeseran pola penyakit, yakni beban penyakit tidak lagi didominasi oleh penyakit menular, tetapi juga penyakit tidak menular seperti hipertensi (Depkes, 2009).

Hipertensi adalah penyakit yang bisa menyerang siapa saja, baik muda maupun tua, orang kaya maupun orang miskin. Hipertensi merupakan salah satu penyakit mematikan di dunia dan saat ini terdaftar sebagai penyakit pembunuh ketiga setelah penyakit jantung dan kanker (Adib, 2009). Berdasarkan hasil penelitian, diketahui bahwa umur dan aktivitas fisik terbukti memiliki hubungan secara signifikan terhadap kejadian hipertensi (Hakim, Ali, \& Tjekyan, 2015). Hal itu didukung dalam penelitian yang dilakukan oleh $\mathrm{Ng}$ et al. (2014) yang berjudul "Smoking Prevalence and Cigarette Consumption in 187 Countries, 1980-2012", bahwa jumlah perokok pria di Indonesia menduduki peringkat kedua tertinggi di dunia sebesar 57 persen dan perokok wanita menduduki peringkat ke enam sebanyak 3,6 persen.

Penyakit terbanyak pada lanjut usia berdasarkan Riset Kesehatan Dasar tahun 2013 adalah hipertensi $(57,6 \%)$, artritis $(51,9 \%)$, stroke $(46,1 \%)$, masalah gigi dan mulut $(19,1 \%)$, penyakit paru obstruktif menahun $(8,6 \%)$, dan diabetes mellitus $(4,8 \%)$. Sementara itu dengan bertambahnya usia, gangguan fungsional akan meningkat dengan ditunjukkan terjadinya disabilitas (Zaenurrohmah \& Rachmayanti, 2017). Sleman merupakan salah satu kabupaten yang berada di Provinsi DI Yogyakarta dengan prevalensi hipertensi pada tahun 2012 sebesar 1.639 per 100.000 penduduk. Pada tahun 2010, 2011, dan 2012 hipertensi menjadi penyakit tidak menular tertinggi di Kabupaten Sleman. Berdasarkan "Profil Kesehatan Sleman tahun 2012", hipertensi merupakan penyakit dengan kasus terbanyak yang diderita pada pasien rawat jalan puskesmas di Kabupaten Sleman dengan 10.893 kasus $(22,8 \%)$ (Dinas Kesehatan Kabupaten Sleman, 2014). Berdasarkan laporan surveilans terpadu penyakit (STP) puskesmas Kabupaten Sleman tahun 2012, dari 25 puskemas di Kabupaten Sleman, Puskesmas Gamping 2 termasuk salah satu puskesmas yang berada di Kabupaten Sleman dengan kasus hipertensi sebanyak 700 kasus.

Studi pendahuluan peneliti lakukan di posyandu lansia wilayah kerja Puskesmas Gamping 2 Yogyakarta dengan mewawancarai 4 penderita hipertensi terdiri atas 2 laki-laki dan 2 perempuan dengan kisaran umur lebih dari 50 tahun. Hasilnya menyatakan bahwa penderita hanya mengetahui bahwa cara untuk menurunkan tekanan darah ialah dengan mengonsumsi obat-obatan yang diberikan oleh tenaga kesehatan dan belum pernah melakukan terapi relaksasi. Gejala yang timbul seperti nyeri kepala dan leher atau gejala lain membuat penderita hipertensi 
tidak nyaman dan mengganggu kualitas tidur dan memengaruhi tingkat stres.

Salah satu penyebab peningkatan tekanan darah pada hipertensi ialah stres (Hermawan, 2014). Hasil penelitian Saputri (2010) tentang hubungan stres dengan hipertensi pada penduduk Indonesia tahun 2007 menyatakan bahwa risiko stres terhadap terjadinya hipertensi berbeda pada masingmasing kelompok umur. Dalam efek interaksi, faktor risiko yang satu dapat memodifikasi dengan faktor risiko yang lainnya lainnya secara timbal balik. Hal tersebut menunjukkan bahwa stres mungkin tidak secara langsung menyebabkan hipertensi, tetapi stres diperkirakan menyebabkan peningkatan tekanan darah ulang yang akhirnya dapat menyebabkan hipertensi.

Selain berpengaruh terhadap tingkat stress, hipertensi juga berhubungan dengan kualitas tidur. Kelainan tidur terjadi dalam persentase yang besar pada populasi dan biasanya tidak dibahas sebagai bagian dari evaluasi medis secara lengkap. Jika tidak diidentifikasi dan diobati dengan baik, gangguan tidur dapat menyebabkan atau memperburuk gangguan medis dan psikiatris seperti hipertensi, penyakit pembuluh darah koroner atau otak, obesitas, dan depresi. Tidur yang tidak adekuat dan kualitas tidur buruk dapat mengakibatkan gangguan keseimbangan fisiologi dan psikologi (Ernawati, Syauqy, \& Haisah, 2017).

Kejadian hipertensi terus meningkat tiap tahun dan masalah yang sering terjadi pada pasien hipertensi ialah pengobatan, mengubah gaya hidup, dan adanya komplikasi akibat hipertensi. Pengobatan penyakit hipertensi dapat berupa farmakologis dan nonfarmakologis. Pengobatan hipertensi membutuhkan waktu yang lama dan membutuhkan biaya yang besar. Oleh karena itu, perlu dipertimbangkan untuk menggunakan pendekatan nonfarmakologis yang sifatnya alami untuk memperbaiki kualitas tidur dan mengendalikan tingkat stres. Penelitian tentang terapi relaksasi untuk penderita sudah banyak dilakukan, tetapi berdasarkan latar belakang tersebut, peneliti ingin menerapkan terapi nonfarmakologi progressive muscle relaxation dan slow deep breathing yang dapat digunakan untuk meningkatkan kualitas tidur dan menurunkan tingkat stres pada penderita hipertensi.

\section{METODE}

Desain yang digunakan dalam penelitian ini adalah "quasi experimental design with comparison group". Pada penelitian ini dibandingkan perbedaan kualitas tidur dan tingkat stres pada penderita hipertensi, yaitu pada kelompok intervensi gabungan antara progressive muscle relaxation dan slow deep breathing; kelompok kontrol 1 dengan progressive muscle relaxation, sedangkan kelompok kontrol 2 dengan perlakuan slow deep breathing.

Populasi pada penelitian ini ialah semua penderita hipertensi primer yang berumur lebih dari 40 tahun yang rutin kontrol di Puskesmas Gamping 2 Yogyakarta. Data yang diambil ialah data bulan Mei 2015 yang berjumlah 121 orang. Teknik purposive sampling untuk menentukan responden yang akan dipakai dalam penelitian. Peneliti menghindari adanya drop out dengan menambahkan $10 \%$ dari perkiraan besar sampel, dari 1,8 dibulatkan menjadi 2 sehingga besar sampel sejumlah 20 responden. Total besar sampel minimal untuk kelompok perlakuan dan kontrol ialah 60 responden.

Peneliti menentukan wilayah kerja Puskesmas Gamping 2 sebagai tempat penelitian untuk kelompok kontrol 1 dan 2 maupun kelompok intervensi. Sebelumnya, peneliti melakukan uji etik di Komite Etik Penelitian FKIK Universitas Muhammadiyah Yogyakarta. Setelah itu, peneliti melakukan 
pengambilan data, dimulai dari nama dan alamat tempat tinggal penderita hipertensi yang rutin kontrol di Puskesmas Gamping 2. Pengukuran pre-test untuk kualitas tidur dan tingkat stres dilakukan pada hari ke-0. Setelah itu, responden diajari oleh peneliti dan asisten peneliti terkait teknik progressive muscle relaxation, yaitu prosedur untuk mendapatkan relaksasi pada otot melalui dua langkah. Langkah pertama adalah dengan memberikan trgangan pada suatu kelompok otot dan kedua dengan menghentikan tegangan tersebut kemudian memusatkan perhatian terhadap bagimana otot tersebut menjadi rileks, merasakan sensasi relaks secara fisik dan tegangannya menghilang (Syarif \& Putra, 2014). Kemudian dilanjutkan slow deep breathing yang merupakan teknik napas dalam dan lambat dengan hitungan inspirasi 3 detik melewati hidung, ditahan selama 3 detik, dilanjutkan ekspirasi melewati mulut selama 6 detik (University of Pittsburgh Medical Centre, 2003).

Kedua intervensi tersebut dilakukan selama 15 hari. Pada hari ke-15 dilakukan post-test menggunakan PSQI (Pittsburgh Sleep Quality Index) untuk mengukur kualitas tidur dengan nilai validitas 0,89 dan reliabilitas sebesar 0,73 . Total skor diperoleh dengan menjumlahkan skor komponen 1-7 dengan rentang 0-21. Skor lebih dari 5 mengindikasikan kualitas tidur yang buruk. Kualitas tidur menggunakan skala data interval. PSS (perceived stress scale) digunakan untuk mengukur tingkat stres dengan nilai validitas 0,85 dan reliabilitas sebesar 0,75 . Penilaian stres berdasarkan skor yang diperoleh dari kuesioner. Skor yang tinggi mengindikasikan bahwa responden mengalami stres. Skala data tingkat stres menggunakan skala data interval. Analisis data dalam penelitian ini menggunakan Anova dilanjutkan uji post-hoc Bonferroni. 


\section{HASIL}

\section{Karakteristik Responden}

Tabel 1. Distribusi responden berdasarkan jenis kelamin, pendidikan, pekerjaan, riwayat keluarga, riwayat merokok, riwayat alkohol, dan lamanya hipertensi di wilayah kerja Puskesmas Gamping 2 Yogyakarta JuliAgustus 2015

\begin{tabular}{|c|c|c|c|c|c|c|c|}
\hline \multirow[t]{2}{*}{ Karakteristik Responden } & \multicolumn{2}{|c|}{$\begin{array}{l}\text { Kelompok } \\
\text { Intervensi }\end{array}$} & \multicolumn{2}{|c|}{$\begin{array}{c}\text { Kelompok } \\
\text { Kontrol } 1\end{array}$} & \multicolumn{2}{|c|}{$\begin{array}{l}\text { Kelompok } \\
\text { Kontrol } 2\end{array}$} & \multirow[t]{2}{*}{$p$ value } \\
\hline & $f$ & $\%$ & $f$ & $\%$ & $f$ & $\%$ & \\
\hline \multicolumn{8}{|l|}{ Jenis Kelamin } \\
\hline Laki-laki & 7 & 35 & 7 & 35 & 7 & 35 & 0,999 \\
\hline Perempuan & 13 & 65 & 13 & 65 & 13 & 65 & \\
\hline \multicolumn{8}{|l|}{ Pendidikan } \\
\hline Tidak sekolah & - & - & - & - & - & - & \\
\hline $\mathrm{SD}$ & 3 & 15 & 3 & 15 & 5 & 25 & \\
\hline SLTP & 7 & 35 & 10 & 50 & 10 & 50 & 0,997 \\
\hline SLTA & 7 & 35 & 5 & 25 & 4 & 20 & \\
\hline Perguruan tinggi & 3 & 15 & 2 & 10 & 1 & 5 & \\
\hline \multicolumn{8}{|l|}{ Pekerjaan } \\
\hline Tidak bekerja & 5 & 25 & 4 & 20 & 8 & 40 & \\
\hline PNS/TNI/Polri & - & - & 1 & 5 & 1 & 5 & \\
\hline Karyawan swasta & 12 & 60 & 11 & 55 & 7 & 35 & 1,000 \\
\hline Wiraswasta & 2 & 10 & 4 & 20 & 3 & 15 & \\
\hline Petani & 1 & 5 & - & - & 1 & 5 & \\
\hline \multicolumn{8}{|c|}{ Riwayat Keluarga dengan Hipertensi } \\
\hline Ada & 14 & 70 & 14 & 70 & 16 & 80 & 0,998 \\
\hline Tidak & 6 & 30 & 6 & 30 & 4 & 20 & \\
\hline \multicolumn{8}{|l|}{ Riwayat Merokok } \\
\hline Ada & 5 & 25 & 7 & 35 & 6 & 30 & 1,000 \\
\hline Tidak & 15 & 75 & 13 & 65 & 14 & 70 & \\
\hline \multicolumn{8}{|l|}{ Riwayat Alkohol } \\
\hline Ada & - & - & - & - & - & - & \\
\hline Tidak & 20 & 100 & 20 & 100 & 20 & 100 & \\
\hline \multicolumn{8}{|l|}{ Terdiagnosis Hipertensi } \\
\hline 1 tahun & 2 & 10 & t & 25 & 4 & 20 & \\
\hline $1-3$ tahun & 8 & 40 & & 40 & 10 & 50 & 0,593 \\
\hline$>3$ tahun & 10 & 50 & r & 35 & 6 & 30 & \\
\hline
\end{tabular}

Berdasarkan Tabel 1, sebagian besar responden adalah perempuan sebanyak $65 \%$. Tingkat pendidikan responden sebnayak $45 \%$ setingkat SLTP. Berdasarkan pekerjaan, responden paling banyak berprofesi sebagai karyawan swasta sebanyak $50 \%$. Mayoritas responden memiliki riwayat keluarga yang mengalami hipertensi $73,3 \%$, sedangkan untuk riwayat merokok $70 \%$ responden tidak merokok. Seluruh responden tidak mempunyai riwayat meminum alkohol, sedangkan untuk lamanya terdiagnosis hipertensi sebanyak $43,3 \%$ berada pada rentang 1-3 tahun. 
Tabel 2. Kualitas tidur dan tingkat stres pada kelompok intervensi, kelompok kontrol 1, dan kelompok kontrol 2 (pre-test hari ke-0)

\begin{tabular}{ccccc}
\hline \multicolumn{1}{c}{ Variabel } & $\begin{array}{c}\text { Kelompok } \\
\text { Intervensi }\end{array}$ & $\begin{array}{c}\text { Kelompok } \\
\text { Kontrol 1 }\end{array}$ & $\begin{array}{c}\text { Kelompok } \\
\text { Kontrol 2 }\end{array}$ & p value \\
\hline Kualitas Tidur & $7,05 \pm 2,24$ & $7,90 \pm 1,92$ & $7,40 \pm 1,79$ & 0,403 \\
Tingkat Stres & $18,45 \pm 2,14$ & $19,60 \pm 2,44$ & $19,35 \pm 2,66$ & 0,422 \\
\hline
\end{tabular}

Berdasarkan Tabel 2 analisis perbedaan ketiga kelompok pada kualitas tidur dan tingkat stres didapatkan hasil $p>0,05$ berarti tidak ada perbedaan yang signifikan antara ketiga kelompok tersebut untuk penilaian pre-test.

\section{Kualitas Tidur dan Tingkat Stres}

Tabel 3. Descriptives pre test (hari ke-0) dan post-test (hari ke-15) variabel kualitas tidur dan tingkat stres

\begin{tabular}{lccccccc}
\hline \multicolumn{1}{c}{ Variabel } & \multicolumn{2}{c}{ Kelompok } & Mean & Min & Max & SD & p value \\
\hline K u a I i t a s & Intervensi & Pre-test & 7,05 & 4 & 12 & 2,235 & 0,000 \\
Tidur & (PMR \& SDB) & Post-test & 4,70 & 2 & 11 & 2,614 & \\
& Kontrol 1 & Pre-test & 7,90 & 5 & 11 & 1,917 & 0,000 \\
& PMR & Post-test & 6,65 & 4 & 10 & 1,785 & \\
Tingkat stres & Kontrol 2 & Pre-test & 7,40 & 4 & 10 & 1,789 & 0,000 \\
& SDB & Post-test & 6,15 & 2 & 9 & 2,033 & \\
& Intervensi & Pre-test & 18,45 & 14 & 22 & 2,139 & 0,000 \\
& (PMR \& SDB) & Post-test & 12,80 & 9 & 20 & 2,505 & \\
& Kontrol 1 & Pre-test & 19,60 & 14 & 24 & 2,437 & 0,000 \\
& PMR & Post-test & 13,20 & 10 & 17 & 2,142 & \\
& Kontrol 2 & Pre-test & 19,35 & 15 & 24 & 2,661 & 0,000 \\
& SDB & Post-test & 15,10 & 9 & 20 & 2,532 & \\
\hline
\end{tabular}

Berdasarkan Tabel 3 didapatkan hasil bahwa kualitas tidur dan tingkat stres pada masing-masing kelompok mengalami penurunan rata-rata mengindikasikan bahwa terdapat peningkatan kualitas tidur dan penurunan tingkat stres.

\section{Analisis variabel kualitas Tidur}

Tabel 4. Analisis Anova pada kelompok intervensi, kelompok kontrol 1 dan kelompok kontrol 2 terhadap variabel kualitas tidur (post-test hari ke-15)

\begin{tabular}{llcc}
\hline & Variabel & f & P value \\
\hline Kualitas & PMR dan SDB & 3,946 & 0,025 \\
Tidur & (Intervensi) & & \\
& PMR (Kontrol 1) & & \\
& SDB (Kontrol 2) & \\
\hline
\end{tabular}

Berdasarkan Tabel 4 didapatkan hasil $p<0,05$, berarti terdapat perbedaan yang signifikan antara ketiga kelompok dalam peningkatan kualitas tidur. Pengukuran data tersebut dilakukan pada hari ke-15. 
Tabel 5. Analisis uji post-hoc Bonferroni pada kelompok intervensi, kelompok kontrol 1 dan kelompok kontrol

\begin{tabular}{|c|c|c|c|}
\hline $\begin{array}{c}\text { (I) } \\
\text { responden }\end{array}$ & $\begin{array}{c}(\mathrm{J}) \\
\text { responden }\end{array}$ & $\begin{array}{c}\text { Mean } \\
\text { Difference }\end{array}$ & Sig. \\
\hline PMR dan & PMR & $-1,792^{*}$ & 0,030 \\
\hline \multicolumn{4}{|l|}{ SDB } \\
\hline & SDB & $-1,466$ & 0,107 \\
\hline \multirow[t]{2}{*}{ PMR } & PMR dan SDB & $1,782^{*}$ & 0,030 \\
\hline & SDB & 0,326 & 1,000 \\
\hline \multirow[t]{2}{*}{ SDB } & PMR dan SDB & 1,466 & 0,107 \\
\hline & PMR & $-0,326$ & 1,000 \\
\hline
\end{tabular}

Data hasil uji post-hoc dengan ketentuan (I-J) jika hasil yang diperoleh nilainya positif $(+)$, perlakuan yang baik adalah kelompok (I). Sebaliknya, jika yang diperoleh hasilnya negatif (-), perlakuan kelompok (J) lebih baik dengan nilai sig. $<0,05$. Berdasarkan analisis tersebut, pada Tabel 5 terdapat perbedaan antara perlakuan PMR dan SDB secara bersama dibandingkan dengan PMR dengan nilai (Sig. $=0,030)$, hasil mean difference menunjukkan negatif (-) berarti perlakuan progressive muscle relaxation (PMR) secara terpisah adalah yang paling berpengaruh untuk meningkatkan kualitas tidur.

\section{Analisis Variabel Tingkat Stres}

Tabel 6. Analisis Anova pada kelompok intervensi, kelompok kontrol 1 dan kelompok kontrol 2 terhadap

\begin{tabular}{|c|c|c|}
\hline Variabel & $\mathbf{F}$ & p value \\
\hline Tingkat PMR dan SDB & 5,091 & 0,009 \\
\hline Stres $\quad$ PMR & & \\
\hline SDB & & \\
\hline
\end{tabular}

Berdasarkan Tabel 6 didapatkan hasil signifikan antara ketiga kelompok untuk $p<0,05$, berarti terdapat perbedaan yang menurunkan tingkat stres.

Tabel 7. Analisis uji post-hoc Bonferroni pada kelompok intervensi, kelompok kontrol 1, dan kelompok kontrol 2 terhadap variabel tingkat stres (post-test hari ke-15)

\begin{tabular}{|c|c|c|c|}
\hline $\begin{array}{c}\text { (I) } \\
\text { responden }\end{array}$ & $\begin{array}{c}\text { (J) } \\
\text { responden }\end{array}$ & $\begin{array}{c}\text { Mean } \\
\text { Difference }\end{array}$ & Sig. \\
\hline \multirow[t]{2}{*}{ PMR dan SDB } & PMR & $-0,100$ & 1,000 \\
\hline & SDB & $-2,153^{*}$ & 0,021 \\
\hline \multirow[t]{2}{*}{ PMR } & PMR & $-0,100$ & 1,000 \\
\hline & $\begin{array}{l}\text { SDB } \\
\text { SDB }\end{array}$ & $-2,052^{*}$ & 0,025 \\
\hline \multirow[t]{2}{*}{ SDB } & PMR & $-2,153^{*}$ & 0,021 \\
\hline & $\begin{array}{l}\text { SDB } \\
\text { PMR }\end{array}$ & $-2,052^{*}$ & 0,025 \\
\hline
\end{tabular}

Berdasarkan analisis pada Tabel 7 breathing (SDB) secara bersamaan dengan terdapat dua nilai significan. Pertama, pada $S D B$ nilai sig. $=0,021$. Hasil mean difference kelompok perbandingan antara progressive menunjukan negatif $(-)$ berarti perlakuan $(\mathrm{J})$ muscle relaxation (PMR) dan slow deep lebih baik, yaitu SDB secara terpisah. Kedua, 
perbandingan kelompok PMR dengan SDB nilai sig. $=0,025$ hasil mean difference menunjukan negatif (-) berarti perlakuan SDB secara terpisah lebih baik. Dapat disimpulkan bahwa yang paling baik atau berpengaruh untuk menurunkan tingkat stres lalah dengan relaksasi SDB secara terpisah.

\section{DISKUSI}

Hasil uji statistik kualitas tidur dengan kuesioner Pittsburgh Sleep Quality Index (PSQI) setelah intervensi pada ketiga kelompok tersebut mengalami perbedaan yang signifikan dengan nilai $p=0,025$. Hal tersebut berarti terdapat perbedaan hasil antara kelompok intervensi, kontrol 1, dan kontrol 2.

Penderita hipertensi primer mempunyai gejala seperti sakit kepala dan nyeri leher bagian kuduk sehingga menyebabkan tegangan pada otot (Nurman, 2017). Hasil penelitian ini sesuai dengan teori yang menyatakan bahwa relaksasi otot progresif merupakan suatu metode untuk membantu menurunkan tegangan sehingga otot tubuh menjadi rileks. Relaksasi otot progresif bertujuan menurunkan kecemasan, stres, otot tegang dan kesulitan tidur. Pada saat tubuh dan pikiran rileks, secara otomatis ketegangan yang seringkali membuat otototot mengencang akan diabaikan (Tyani, Utomo, \& Hasneli, 2015).

Penelitian dari Marks (2011) menyatakan bahwa relaksasi otot progresif efektif meningkatkan kualitas tidur jika dilakukan selama secara teratur dalam waktu 6 minggu. National Center for Complementary and Alternative Medicine (2010) juga menyebutkan efek dari relaksasi otot progresif membantu lansia dalam meningkatkan kebutuhan tidurnya dan menurunkan gangguan tidur yang cenderung meningkat pada lansia. Relaksasi ini lebih baik dilakukan daripada teknik meditasi. Dengan demikian, intervensi keperawatan dalam meningkatkan pemenuhan kebutuhan tidur dapat dilakukan dengan melakukan teknik relaksasi, yaitu relaksasi otot progresif sehingga dapat memenuhi kebutuhan tidur secara kualitas kepada lansia (Berstein, Berkovec, \& HazlettStevens, 2000).

Hasil ini didukung oleh pendapat Conrad \& Roth (2007) yang menjelaskan bahwa pemberian relaksasi otot progresif memengaruhi pemenuhan kebutuhan tidur lansia yang didasarkan pada cara kerja sistem saraf simpatis dan parasimpatis yang bekerja timbal balik memengaruhi organorgan yang ada di dalam tubuh sehingga mampu mengurangi ketegangan. Relaksasi yang diberikan kepada lansia mampu meningkatkan relaksasi otot-otot besar sehingga dapat meningkatkan kenyamanan, terpenuhinya kebutuhan tidur secara kuantitas dan kualitas.

Teori yang mendukung pengaruh teknik relaksasi napas dalam adalah teknik relaksasi Benson yang merupakan teknik latihan napas. Dengan latihan napas yang teratur dan dilakukan dengan benar, tubuh akan menjadi lebih rileks, menghilangkan ketegangan saat mengalami stress, dan bebas dari ancaman. Perasaan rileks akan diteruskan ke hipotalamus untuk menghasilkan corticotropin releasing factor (CRF). Selanjutnya CRF merangsang kelenjar pituitary untuk meningkatkan produksi proopioidmelanocortin (POMC) sehingga produksi enkefalin oleh medulla adrenal meningkat. Kelenjar pituitari juga menghasilkan endorfin sebagai neurotransmitter. Dengan meningkatnya enkefalin dan endorfin, pasien akan merasa lebih rileks dan nyaman dalam tidurnya sehingga kualitas tidurnya menjadi baik (Hazila, 2014).

Penelitian mengenai teknik relaksasi Benson (napas dalam) telah dilakukan 
oleh Rambod et al. (2013) dengan judul penelitian “The Effect of Benson's Relaxation Technique on the Quality of Sleep of Iranian Hemodialysis Patient: A Randomized Trial". Hasil menunjukkan perbedaan yang signifikan antara kelompok intervensi dan kelompok kontrol pasien hemodialisis yang mengalami gangguan tidur mengenai perubahan nilai rata-rata dari Pittsburgh Sleep Quality Indeks (PSQI), seperti gangguan tidur, disfungsi siang hari, penggunaan obat tidur, dan kualitas tidur subjektif serta skor PSQI secara keseluruhan pada minggu ke-8 intervensi ( $p$ $<0,05$ ).

Berdasarkan hal tersebut, peneliti menganalisis bahwa kedua teknik tersebut sangat berperan dalam meningkatkan kerja saraf parasimpatis sehingga mengeluarkan hormon endorfin yang menyebabkan perasaan rileks. Akan tetapi, berdasarkan hasil penelitian bahwa (progressive muscle relaxation) PMR merupakan teknik yang paling baik untuk meningkatkan kualitas tidur, peneliti berpendapat bahwa selain menimbulkan relaksasi, latihan otot akan menimbulkan fatigue yang akan berpengaruh terhadap kualitas tidur maka kualitas tidur akan meningkat. Berdasarkan analisis pada uji beda yang tidak berpasangan terhadap tingkat stres didapatkan hasil $p=0,009$. Berarti terdapat perbedaan yang signifikan skor tingkat stres setelah dilakukan latihan antara kelompok intervensi, kelompok kontrol 1, dan kelompok kontrol 2.

Smeltzer \& Bare (1996/2002) mengatakan bahwa tujuan latihan relaksasi ialah untuk menghasilkan respons yang dapat memerangi respons stres, sedangkan Potter (2006) mengatakan bahwa relaksasi bertujuan menurunkan sistem saraf simpatis, meningkatkan aktivitas parasimpatis, menurunkan metabolisme, menurunkan tekanan darah dan denyut nadi, dan menurunkan konsumsi oksigen.
Pada saat kondisi rilek tercapai maka aksi hipotalamus akan menyesuaikan dan terjadi penurunan aktivitas sistem saraf simpatis dan parasimpatis. Urutan efek fisiologis dan gejala maupun tandanya akan terputus dan stres psikologis akan berkurang. Tehnik relaksasi yang biasa digunakan ialah relaksasi otot, relaksasi dengan imajinasi terbimbing, dan respons relaksasi dari Benson (Smeltzer \&Bare, 1996/2002).

Pada waktu orang mengalami ketegangan dan kecemasan, yang bekerja ialah sistem saraf simpatis sehingga denyut jantung, tekanan darah, jumlah pernapasan, aliran darah ke otot, dan dilatasi pupil sering meningkat. Pada kondisi stres yang terusmenerus, mungkin muncul efek negatif terhadap kesehatan seperti tekanan darah

tinggi, kolesterol tinggi, distres gastrointestinal, dan melemahnya sistem imun (Putra, 2013).

Berdasarkan hasil penelitian, teknik yang paling baik untuk menurunkan tingkat stres adalah slow deep breathing (SDB) yang dilakukan secara terpisah. Peneliti menganalisis bahwa SDB lebih berfokus pada relaksasi untuk otak sehingga berpengaruh psikologis sehingga cenderung untuk menurunkan tingkat stres. Latihan napas dalam dan lambat dapat menurunkan tingkat kecemasan melalui sistem saraf otonom. Napas dalam dan lambat dapat menimbulkan efek relaksasi. Napas dalam dapat memengaruhi perubahan biokimia tubuh, seperti meningkatkan substansi yang menyebabkan relaksasi (endorfin) dan menurunkan adrenalin (Sepdianto, Nurachmah, \& Gayatri, 2010).

Berdasarkan penelitian Putra (2013), melakukan napas dalam dan lambat dapat meningkatkan kinerja saraf parasimpatis sehingga meningkatkan pelepasan hormon dalam sistem neuroendokrin yang 
meningkatkan ketenangan dan status kesadaran mental.

\section{SIMPULAN}

Berdasarkan hasil penelitian terdapat perbedaan yang bermakna antara klompok intervensi, kelompok kontrol 1, dan kelompok 2 dalam peningkatan kualitas tidur. Terdapat perbedaan yang bermakna antara klompok intervensi, kelompok kontrol 1, dan kelompok 2 dalam penurunan tingkat stres.

Untuk keefektifan teknik relaksasi, didapatkan hasil bahwa kelompok kontrol 1 dengan intervensi progressive muscle relaxation paling efektif untuk meningkatkan kualitas tidur daripada kelompok intervensi dan kelompok kontrol 2. Keefektifan teknik relaksasi slow deep breathing pada kelompok kontrol 2 paling efektif untuk menurunkan tingkat stres daripada kelompok intervensi dan kelompok kontrol 1.

\section{DAFTAR PUSTAKA}

Adib, M. (2009). Cara mudah memahami dan menghindari hipertensi, jantung, dan stroke. Yogyakarta: Dianloka Pustaka.

Adriani, M. \& Wirjatmadi, B. (2012). Peranan gizi dalam siklus kehidupan (Edisi 1). Jakarta: Kencana Prenada Media Group.

Berstein, D. A, Berkovec, T. D., \& HazlettStevens, H. (2000). New direction in progressive relaxation training: $A$ guidebook for helping professionals. USA: Praeger Publishers.

Conrad, A. \& Roth, W.T. (2007). Muscle relaxation therapy for anxiety disorders: It works but how?. J Anxiety Disord, 21(3): 243-264.

Departemen Kesehatan RI. (2009). Pedoman Pengendalian Faktor Risiko Penyakit Jantung dan Pembuluh Darah. Jakarta: Direktorat Jendral PP \& PL.

Dinas Kesehatan Kabupaten Sleman. (2014). Profil Kesehatan Sleman Tahun 2013.
Retrieved from https://dinkes.slemankab. go.id/wp-content/uploads/2014/01/ PROFIL-2013.pdf

Ernawati, Syauqy, A., \& Haisah, S. (2017). Gambaran kualitas tidur dan gangguan tidur pada lansia di Panti Sosial Tresna Werdha Budi Luhur Jambi. Retrieved from http://repository.unja.ac.id/2381/1/ JURNAL.pdf

Fan, K. W. (2005). National center and for complementary and alternative medicine website. J. Med Libr Assoc, 93(3): 410412.

Hakim, A., Ali, Z., dan Tjekyan, S. (2015). Prevalensi dan faktor risiko hipertensi di Kecamatan llir Timur II Palembang tahun 2012. MKS, 47(1), 51-60.

Hazila, E. (2014). Pengaruh teknik relaksasi benson terhadap skor kualitas tidur pasien yang menjalani hemodialisis di unit hemodialisis RSUP Dr. M. Djamil Padang (Skripsi). Fakultas Keperawatan Universitas Andalas, Padang, Indonesia.

Hermawan, F. (2014). Hubungan tingkat stres dengan tekanan darah pada lansia hipertensi di Gamping Sleman Yogyakarta (Skripsi). Sekolah Tinggi llmu Kesehatan 'Aisyiyah, Yogyakarta, Indonesia.

Marks, T. I. (2011). Master your sleep- Proven methods simplified. Minneapolis: Bascom Hill Publishing Group.

$\mathrm{Ng}$, M., Freeman, M. K., Fleming, T. D., Robinson, M., Dwyer-Lindgren, L., Thomson, B., Wollum, A., Sanman, E., Wulf, S., Lopez, A. D., Murray, C. J, Gakidou, E. (2014). Smoking prevalence and cigarette consumption in 187 countries, 1980-2012. JAMA, 311:2: 183-192.

Potter, P. A. (2006). Fundamentals of Nursing: Concepts, process, and practice (4th edition). (Alih bahasa: Renata Komalasari). Jakarta: Penerbit Buku Kedokteran EGC. 
Putra, E. K. (2013). Pengaruh latihan nafas dalam terhadap perubahan tekanan darah pada penderita hipertensi di wilayah Kecamatan Karas Kabupaten Magetan (Skripsi). Universitas Muhammadiyah Surakarta, Jawa Tengah, Indonesia.

Syarif, H. \& Putra, A. (2014). Pengaruh progressive muscle relaxation terhadap penurunan kecemasan pada pasien kanker yang menjalani kemoterapi: A randomized clinical trial. Idea Nursing Journal, 5(3): 1-8.

Rambod, M., Pourali-Mohammadi, N., Pasyar, N., Rafii, F., Sharif, F. (2013). The effect of Benson's relaxation technique on the quality of sleep of Iranian hemodialysis patient: A randomized trial. Complement Ther Med, 21(6): 577-584.

Richmond, R. L. (2009). Progressive Muscle Relaxation. Retrieved from http://www. guidetopsychology.com/pmr.htm.

Saputri, D. E. (2010). Hubungan stres dengan hipertensi pada penduduk di Indonesia tahun 2007 (Analisis data Riskesdas tahun 2007) (Tesis). Fakultas Kesehatan Masyarakat Universitas Indonesia, Jakarta, Indonesia.

Sepdianto, T. C., Nurachmah, E., \& Gayatri, D. (2010). Penurunan tekanan darah dan kecemasan melalui latihan slow deep breathing pada pasien hipertensi primer. JKI, 13(1): 37-41.

Smeltzer, S. C. \& Bare, B. G. (2002). Brunner and Suddarth's textbook of medical surgical nursing (8th edition). (Alih bahasa: Agung Waluyo, Yasmin Asih, Juli, Kuncara, I Made Kariasa). Jakarta: Penerbit Buku Kedokteran EGC. (Buku asli diterbitkan 1996).

Sleep quality assessment (PSQI). (2003). Retrieved from uacc.arizona.edu/ sites/default/files/psqi_sleep_ questionnaire_1_pg.pdf.

Tyani, E. S., Utomo, W., Hasneli, Y. (2015).
Efektivitas relaksasi otot progresif terhadap tekanan darah pada pasien hipertensi esensial. JOM 2(2): 10681075.

Zaenurrohmah, D. H. \& Rachmayanti, R. D. (2017). Hubungan pengetahuan dan riwayat hipertensi dengan tindakan pengendalian tekanan darah pada lansia. Jurnal Berkala Epidemiologi, 5(2): 174184. 